\title{
Dane Rudhyar's concept of transpersonal life
}

\author{
Jindřich Veselý
}

https://doi.org/10.14712/25704893.2017.2

\begin{abstract}
Dane Rudhyar was a composer, theosophist, philosopher, artist and a significant astrologer. His conception of transpersonality is crucial in almost all of his works and ideas. The article presents this conception in the context of Rudhyar's transpersonal psychology, philosophy of history, cosmology, metaphysics and also his interpretation of the basic themes and ideas of H. P. Blavatsky's theosophy. Rudhyar's conception of transpersonality is based on an idea that through transpersonal inidividuality there is influence from higher forces or beings in the time and space of our world. The transpersonal life of a person like this has its cosmological and metaphysical aspects; it might be said that transpersonality means completion of inidividual existence, evolution of mankind and cosmos. This way of life also has a profound meaning for spirituality, ethics, esoteric initiation and sexuality. The article deals with Rudhyar's distinction between active and conscious transpersonality, and passive mediumity, too. We also consider connections between Rudhyar's ideas and similar or parallel movements, especially with theosophy, perrenialism, transpersonal movement and New Age. Finally we briefly discuss strong and weak points of Rudhyar's conception, but also limitations of a strictly theoretical approach.
\end{abstract}

Keywords: Transpersonal movement, transpersonal psychology, cosmology, theosophy, perrenialism, New Age
Abstrakt: Dane Rudhyar byl hudební skladatel, theosof, filosof, umělec a význačný astrolog, jehož pojetí transpersonality je klíčové prakticky pro celé jeho dílo i myšlenky. Článek toto pojetí představuje v kontextu Rudhyarovy transpersonální psychologie, filosofie dějin, kosmologie, metafyziky a rovněž jeho interpretace základních témat a idejí theosofie H. P. Blavatské. Rudhyarovo chápání transpersonality je založeno na myšlence, podle níž je transpersonální individualita vykonavatelem vlivu vyšších sil nebo bytostí, které se nacházejí časově či prostorově mimo tento svět. Transpersonální život takové osobnosti má své kosmologické a metafyzické aspekty; dá se říci, že transpersonalita představuje dovršení individuální existence i evoluce lidstva a kosmu. Tento způsob života má rovněž zásadní význam pro spiritualitu, etiku, esoterickou iniciaci a sexualitu. Článek se zabývá také Rudhyarovým odlišením aktivní a uvědomělé transpersonality od pasivní mediumity i souvislostmi Rudhyarových myšlenek s podobnými nebo paralelními hnutími, a to zvláště s theosofí, perenialismem, transpersonálním hnutím a hnutím nového věku. Na závěr krátce probereme silné a slabé stránky Rudhyarova pojetí, ale i omezení, s jakými se potýká přísně teoretický přístup k němu.

Klíčová slova: transpersonální hnutí, transpersonální psychologie, kosmologie, theosofie, perenialismus, new age

Received: 29 June 2016, Accepted: 10 August 2016, Published online: 26 June 2017

Mgr. Jindřich Veselý, Ph.D. student, Department of Comparative Religions, Protestant Theological Faculty of Charles University.

E-mail: jindrich.vesely@email.cz

(C) 2016 Author. This is an open-access article distributed under the terms of the Creative Commons Attribution License (http://creativecommons.org/licenses/by/4.0), which permits unrestricted use, distribution, and reproduction in any medium, provided the original author and source are credited. 
An American composer, astrologer, philosopher, religious thinker and artist of French origin, Dane Rudhyar (1895-1985) is known even in the Czech Republic as a founding figure of contemporary humanistic and transpersonal astrology. Less known is the fact that this thinker was probably the first to employ the word "transpersonal", at least in English, ${ }^{1}$ and that the way he used it was very different from the current use, which is influenced by later transpersonalists. Rudhyar's concept of transpersonality not only encompasses an exceptional outline of spiritual life, but it is also one of the central motifs of his entire spiritual heritage. This text intends to present an overview of Rudhyar's view of transpersonality, its particular aspects and its role in the whole of his thought; the conclusion will try to put it in relation to other more or less related spiritual currents and reflect its strengths as well as problematic aspects.

\section{(1) Transpersonality in the context of Rudhyar's work}

\section{(1.1) Neologism becomes a destiny}

Dane Rudhyar used the word "transpersonal" as early as 1929 in his article On Personal and impersonal which he wrote for The Glass Hive journal, which he was publishing in at that time. Here he says: "A transpersonal behavior is one starting from the universal unconditioned self in Man and using merely the personality as an instrument. Such a behavior will be colored obviously by the personality - but not so much the personality of the actor as the one toward whom the act is directed. It will be colored by the race, time and locality." ${ }^{3}$ In all his work, Rudhyar will invariably hold on to this interpretation of transpersonality as a descent of spiritual influences from the higher levels of reality by means of a human individual, who thus becomes a mere tool or an intermediary for such influence. It is possible to say that in a way this English neologism became his creator's destiny for the rest of his life that encompassed a whole half of the century. Transpersonal influences and the development of corresponding functions in human life occupy a prominent place in Rudhyar's work - and probably in his life as well: ${ }^{4}$ it is possible to say that transpersonality represents a kind of completion or culmination of individual human existence, social development, and human evolution, at least on this planet; moreover, it has cosmic or even eschatological functions. It seems that the development of "transpersonal functions", in Rudhyar's interpretation, forms a kind of core of all his work and that according to him, they represent a spiritual movement of planetary importance, to which he dedicated his work.

DANE Rudhyar, Rhythm of Wholeness: A Total Affirmation of Being (online), Khaldea.com, 1995, accessed March 2016, available online at http://www.khaldea.com/rudhyar/rw/, part 1, chapter 1 , page 1 .

2 DANe Rudhyar, "On personal and impersonal" (online), The Glass Hive (November 1929), accessed March 2016, available online at http://www.khaldea.com/rudhyar/per_imper.shtml.

3 RUDHYAR, "On personal and impersonal", http://www.khaldea.com/rudhyar/per_imper.shtml.

4 See especially Rudhyar, Rhytm of Wholeness, http://www.khaldea.com/rudhyar/rw/, part 1, chapter 1 , page 1 . 


\section{(1.2) Transpersonality in the individual existence, history, human evolution and the story of the cosmos}

First of all, we will take a closer look at how Rudhyar's transpersonality manifests itself in the individual human existence. In his main work dedicated to psychology, with a telling title Beyond Individualism, ${ }^{5}$ Rudhyar distinguishes four gradually developing orders of functions in human beings: biological, social, individual and transpersonal. Biological and social functions, mediated by sexuality and related phenomena such as kinship and social organization, are currently shared by all human beings. That applies also to individual functions, even though only in embryonic form - the full scale individual functions are shared only potentially. Access to growth of individual functions requires development of discursive intellect and its creation implies a painful process of the emergence of a fully developed individuality from the relative safety of wider society's collective matrix and determining forces of its own culture. The process of individualization is, probably inevitably, accompanied by egoism as its shadowy form, which, and that is also Rudhyar's main point, can be overcome only by transcending individualism. Through the rite of passage, in which one devotes his or her entire existence to a higher whole, the individuality reaches self-transcendence and fundamental transformation: becomes completely self-dedicated to larger whole. Thus transformed, the individual acquires on the sensual level compassion or love that Rudhyar connects to the bodhisattva ideal and the revelation of Christ, and on the mental level he develops a "cosmogenic mind" that is able to find cosmic order in chaos and perceive the beauty even in apparent ugliness. "Cosmogenic mind" also brings order to reality. Both compassion and holistic "cosmogenic" minds are transparent and open: they both stem from a principle of mutual interpenetration. Therefore, Agape is connected to cosmogony and vice versa. At the evolutionary point when this becomes more apparent, the existence of individuals fully devoted to the whole becomes univocal and mutually permeable; more importantly, they open themselves to the light of absolute future that Rudhyar, probably inspired by Teilhard de Chardin, describes as a shine emitted by the omega point of human evolution. This is supposed to lead to the transformation of the physical and material reality itself. To achieve final enlightenment means, to Rudhyar, quite literally to be transformed into light. ${ }^{6}$

It is apparent that transpersonality or "fourth order function" represents the fulfillment and transcendence of an individual existence, but not only that. In The Planetarization of Consciousness, ${ }^{7}$ one of his main works, Rudhyar outlines the main phases through which he believes the human society goes. The first phase, the "thesis" of social evolution, is the compulsive and unconscious unanimity of a tribal organization. As its antithesis comes the individualistic and atomized society of today,

5 Dane Rudhyar, Beyond Individualism: The Psychology of Transformation, Wheaton: Quest Book, 1979.

6 See Rudhyar, Beyond Individualism, passim.

7 Dane Rudhyar, The Planetarization of Consciousness, New York: Harper, 1972, 343 p. 
whose main characteristic is the conflict of competing individuals. ${ }^{8}$ The synthesis of both is the society of fullness, ${ }^{9}$ whose core traits will be voluntary and conscious unanimity and that, according to Rudhyar, will organically grow from the communities of individuals fully committed to serve the planetary whole. This society of beings fully committed to serve will form a "Pleroma", a kind of collective being of higher order, that in conditions that can be hardly imagined will transcend both the individual and the collective, while at the same time transmuting the matter itself or the known world. This is how Rudhyar imagined the fulfillment of both social and human evolution. ${ }^{10}$

Nevertheless, this is not the only meaning of transpersonal functions: they also have a cosmogonic purpose. Rudhyar's worldview, deeply influenced especially by Theosophy, is essentially cyclical. The existence of the cosmos is marked by the rhythm of the manifested and unmanifested being. The core archetype or idea that is both the plan of one whole cycle and the motif, which is supposed to undergo a hard and difficult evolution from potentiality to its full actualization, is the archetype of Man. In each cycle this archetype represents the way to resolve the problems and save the failures of the previous cycle. In each of the cycles the author of this archetype is the pleromatic mind that emerged from the previous cycle - and, at the same time, its full actualization is the Pleroma of the following cycle, in other words, the univocal community of transpersonal beings. In The Planetarization of Consciousness, Rudhyar describes this process in an almost Trinitarian way: the Pleroma of the old cycle is the "hidden father" of the new archetype of man or the "son", while the origins of the archetype's actualization or the growth of the divine child is made possible by the mysterious act, in which the Pleroma of the completed cosmic cycle is immersed in the "endless ocean of potentiality" or, figuratively speaking, in the womb of the "eternal virgin", ${ }_{11}$ which thus becomes pregnant and later gives birth to a new cycle, which will be the place of the gradual actualization and realization of the aspects of the archetype of man, until they reach synthesis in the following Pleroma.

In his main work The Rhythm of Wholeness, Rudhyar describes this cyclical movement as a rhythmical interaction of opposing and mutually irreducible principles of subjectivity and objectivity, alternatively called "Day" and "Night". This cyclical movement has four focal points. The first of them is the "cosmic midnight" or the phase of the "divinity", which represents almost full hegemony of the principle of unity. It is here that the Pleroma of the old cycle submerges to the endless potentiality and a new human archetype, the divine child, is born. Then follows the moment in which the opposing forces are of equal strength, but their equilibrium yields to the principle of diversity; this is the point in which the "cosmic egg hatches", in other words the objective reality manifests itself and the material cosmos arises. The next

\footnotetext{
${ }^{8}$ Rudhyar, The Planetarization of Consciousness, p. 19.

${ }^{9}$ Rudhyar, The Planetarization of Consciousness, p. 257-259.

${ }^{10}$ Rudhyar, The Planetarization of Consciousness, p. 178.

"Rudhyar, The Planetarization of Consciousness, p. 129-130.
} 
point is the "midday" point, when the principle of diversity is at the peak of its powers and prevails almost fully. It is here that the human archetype begins to incarnate - its different aspects start to manifest themselves as avataric beings, creators of cultural and civilizational wholes. In the end comes the fourth point, "dusk", when the opposing principles reach equilibrium again, which withdraws not to diversity, as it did during the "dawn", but to the opposing force or the principle of unity, which rules the following period. During this phase the external, manifested world disappears and a sequence of gradually more and more subjective processes of the subjective mind starts to envelop, until another point of cosmic midnight is reached.

It is clear that, according to this cyclical cosmological pattern or myth, humankind is currently on its way to the "gates of the silence" or the point of "dusk", in which the enlightened individuals give rise to a planetary Pleroma. Therefore, emergence of the transpersonal functions is not only a precursor of the fulfillment of the individual odyssey of human beings, social development and evolutionary pathway of the earthly humanity, but also - at least in this aeon - the tidings of the eschaton: the disappearance of the world as we know it and collective transition to a radically different way of being.

Apparently, Rudhyar was convinced that his philosophy is to become a catalyzer of this synthetic process, which will result in a new unity of all different spiritual traditions and their transformation into one primordial tradition, this time enriched by the result of the ending cycle. It will also mean transcendence of the individualistic humanity towards conscious and intentional unanimity of the Pleroma and, finally, also a radical transformation of the world at large.

It should be noted that the motif of transpersonality also has an important meaning in Rudhyar's vast astrological work: the real fulfillment of individual existence symbolized by the cyclical movement of nativity potential development is possible only by the transition to transpersonal existence. This is closely related to the transformation of the nativity itself, which changes its quadripartite nature formed by the two main axis of the radix, into a hexagonal structure..$^{12}$ At the same time the importance of the components of nativity and astrological techniques changes - in the transpersonal sense Rudhyar sees secondary directions as more crucial than the transits, its importance being mainly individual and social. ${ }^{13}$

12 These somehow cryptic passages probably refer to Theosophical tradition regarding the root races of humankind. See also DANE RUDhYAR, "Occult preparations for a New Age" (online), Khaldea. com, 1995, accessed March 2016, available online at http://www.khaldea.com/rudhyar/op/op _c6_p1.php, part 2, chapter 6, p. 1.

${ }_{13}$ To assess Rudhyar's astrological legacy and its relation to transpersonality see both DANE RUDHYAR, "From humanistic to transpersonal astrology" (online), Khaldea.com, 1995, accessed March 2016, available online at http://www.khaldea.com/rudhyar/fromhtot_1.shtml, and especially his main astrological testament. DANE RudhyAR, The Astrology of Transformation, A Multilevel Approach (online) Khaldea.com, 1995, accessed March 2016, available online at http://www .khaldea.com/rudhyar/aoft/, chapter 7, page 2 . 


\section{(2) On transpersonal life}

Probably the single most esoteric of Rudhyar's works is the book Occult preparations for a New Age,${ }^{14}$ which is dedicated to the legacy of H. P. Blavatsky, and was published in 1975 on the occasion of the hundredth anniversary of the founding of the Theosophical Society. In this book Rudhyar largely elaborates on the different aspects of transpersonal existence that is already available for the vanguard of future humanity, those human "mutants", ${ }^{15}$ through which the new age will arrive. The next paragraphs summarize those aspects of transpersonal existence.

\section{(2.1) Two polarities of spiritual life}

In the first part of his treatise on important aspects of transpersonal life, Rudhyar distinguishes two main spiritual orientations, one of them being closely connected to his concept of transpersonality.

Rudhyar notes that the contemporary use of the word "transpersonal" refers more to transcending the level of experience that is generally understood as personal. According to him, the problem lies in the ambivalence of the word "transpersonal": the prefix "trans-" might mean both "out of" or "outside" and "through" or "by means of". As we already mentioned, Rudhyar already used this word in $1929 ;{ }^{16}$ even by then he meant by it the influences of spiritual beings through a person. "The source of that power, consciousness, or activity could certainly be considered as existing beyond the realm of personality, but the activity itself is transpersonal because its most significant feature is its using a person as an instrumentality or agent through which the activity is released in a focused condition. ${ }^{.17}$ Rudhyar insists that the meaning "beyond a person", more frequently used by other authors, is more acceptable for the average mentality formed by science - this kind of mind sees evolution as "ascendence" towards higher levels or transcendence of the borders of individuality. On the other hand, accepting the original interpretation means that the human being must accept "the world-outlook characterizing true Occultism," 18 according to which "the Universe is worked and guided from within outward, controlled and animated by almost endless series of Hierarchies of sentient Beings." 19

Nevertheless, on this level the thing we usually call individuality does not exist, which also clearly means that when they want to exert influence on the human level of reality, these hierarchies of the level above individual choose their representatives

${ }^{14}$ See note 12.

15 DANe Rudhyar, "Human, all too human and beyond" (online), Khaldea.com, 1995, accessed March 2016, available online at http://www.khaldea.com/rudhyar/toohuman.shtml.

${ }^{16}$ RUDHYAR, “On personal and impersonal”, http://www.khaldea.com/rudhyar/per_imper.shtml.

17 Rudhyar, “Occult Preparations for a New Age”, http://khaldea.com/rudhyar/op/op_c8_p1.php, part 3, chapter 8, p. 1 .

18 Rudhyar, “Occult Preparations for a New Age”, http://khaldea.com/rudhyar/op/op_c8_p1.php, part 3, chapter 8, p. 1 .

19 Helena Petrovna Blavatsky, The Secret Doctrine (I:224), quoted in Rudhyar, "Occult Preparations for a New Age", part 3, chapter 8, p. 1. 
or ambassadors among people and they concentrate their energy in them - just like the sunlight needs an intermediary, such as the lens, that would concentrate it and by its means, for example, burn a paper. This is exactly the way transpersonal activity works in Rudhyar's concept.

Other representants of transpersonal psychology or transpersonal movement tend to describe the mystical way as inverse, i.e. ascending. Rudhyar's concept of transpersonality focuses on the opposite path of the avatar, cultural hero, or creative genius. It is through, and in, these beings that the transformative forces required by the current creative process work, and they work more or less consciously. Through them deeds then arise that become "symbols and examples for a whole culture or nation."

Rudhyar then proceeds to characterize the mystic as a person that "deliberately leads a life and tries to reach a mode of consciousness which separates him from what the society in which he is born considers 'norma!.'”21Just as a true occultist (or a transpersonal agent of higher forces), the mystic represents a countercultural influence that polarizes the common society. "The true mystic also comes to experience a death of the natural person in him and a rebirth in a new state illumined by the memory [...] - an ecstatic condition of being and/or consciousness." ${ }^{22}$ This kind of experience can be a reflection of consciousness and of the activity of the transcending, transindividual field of consciousness that the mystic reaches and that can also be reached by chemical means. This transformation occurs mainly in the sphere of feelings, which is the reason why mystics from all times choose metaphors and symbols of love and physical union. Rudhyar calls this journey of human individuality development "anti-individual", as it goes straight against a thousand year long trend towards individualization, representing the intent to return back to a regressive oceanic experiencing of primordial unity. In contrast to this, from the "axial era" at the very latest, the progressive course of human consciousness has been directed towards assimilating quantity or diversity.

In contrast to this, the path of an avatar ${ }^{23}$ progresses in the same direction as the movement of the evolution, while at the same time it defies the "inertia" of the wider society that is reflected in clinging to outdated institutions, dogmas, and structures.

${ }^{20}$ Rudhyar, “Occult Preparations for a New Age”, http://khaldea.com/rudhyar/op/op_c8_p1.php, part 3, chapter 8, p. 1 .

${ }^{21}$ Rudhyar, "Occult Preparations for a New Age", http://www.khaldea.com/rudhyar/op/op_c8 _p2.php, part 3, chapter 8, p. 2.

${ }^{22}$ Rudhyar, "Occult Preparations for a New Age”, http://www.khaldea.com/rudhyar/op/op_c8 _p2.php, part 3, chapter 8, p. 2. It is necessary to add that in the case of the mystic path, Rudhyar admits the possibility of "rebirth" or some other kind of transformation of the mystic's existence. However, probably in connection with his evolutionary concept of human history, he describes this kind of transformation as a matter of an individual level of existence, albeit an extreme one. That is to say, he does not consider it to be a transition towards a transpersonal level of existence. See also conclusion to this article.

${ }^{23}$ Rudhyar uses the term "avatar" for important transpersonal beings, from which stem different sacred traditions and whose influence shaped whole cultures. He considered Buddha and Jesus to be the two most important avatars of contemporary mankind. See also RUDHYAR, Rhytm of Wholeness, http://www.khaldea.com/rudhyar/rw/, part 1, chapter 5, page 3. 
Therefore, the transpersonal being is a reformer, an "agent of destiny." 24 Those prometheic spirits come when it is time for a culture or a civilization to change; their obliviousness in the face of the consequences their transformative acts of defiance against the inertia of the wider society might provoke changes them into "karmayogis". They are the messengers of higher forces that act through them - and those forces do not have to be "good", at least judging from the human point of view: "there are also avatars of Evil." 25 We can conceive them as divine incarnations of the principles or personalities they embody, although Rudhyar would rather use the term "transcarnation": "The fire of transformation burns through the flesh (carne) until its work is done or at least until the disciples attracted to the flame have exhausted their capacity to respond to the fire and the light it radiates." ${ }^{26}$

This path does not exclude mystical union; however, this union has a very different meaning: it does not consist of the ascension of the soul to god or a divine level but of descending influence of the higher forces through an individual, "an answer to a collective human need." ${ }^{27}$ It is possible to say that the avatar comes from up high as an answer to a more or less articulated need of the cultural whole or humanity. He accepts a historically conditioned form and he transforms it from within. "The avataric being can be considered as the earth terminal of a line of transmission of power. He is a magical instrumentality, a mask used in a collective ritual." ${ }^{28}$ The acts of this figure are impersonal - the avatar resembles more an execution of a spiritual quality that through him focuses into a historical situation, than a personality in the usual sense.

Not even important avatars need to be aware of their mission right from the start the mission is reflected more in their apparently enlightened actions than in knowledge which depends on the situation they have been born into. It is possible to speak of their destiny in terms of reincarnation, but Rudhyar insists that it is not their concrete individual soul that acts, but the Man as himself, in other words, one of the aspects of the archetype of man, a kind of spiritual quality. "It is the performance of a role which releases the creative potentiality inherent in a specific moment in the great play of man's evolution. In this performance the performer, having totally identified himself with the role, is pouring his life-substance into the action. He is the action as well as the actor; and he "is also, in a sense, that which is acted upon, because spiritually speaking the three are one". ${ }^{29}$ In the case of less important persons this

${ }^{24}$ Rudhyar, "Occult Preparations for a New Age", http://www.khaldea.com/rudhyar/op/op_c8 _p3.php, part 3, chapter 8, p. 3.

${ }^{25}$ RudhyAR, "Occult Preparations for a New Age", http://www.khaldea.com/rudhyar/op/op_c8 _p4.php, part 3, chapter 8, p. 4.

${ }^{26}$ Rudhyar, "Occult Preparations for a New Age", http://www.khaldea.com/rudhyar/op/op_c8 _p4.php, part 3, chapter 8, p. 4.

27 Rudhyar, "Occult Preparations for a New Age", http://www.khaldea.com/rudhyar/op/op_c8 _p4.php, part 3, chapter 8, p. 4.

${ }^{28}$ Rudhyar, "Occult Preparations for a New Age", http://www.khaldea.com/rudhyar/op/op_c8 _p4.php, part 3, chapter 8, p. 4.

29 RudhyAR, "Occult Preparations for a New Age", http://www.khaldea.com/rudhyar/op/op_c8 _p4.php, part 3, chapter 8, p. 4. 
might lead to strong passions, sometimes even hubris, but the pride of great avatars is generally connected to inner humility in the face of the real source of their acts: "Reverence is the very soul of true heroism; reverence before the supreme and always mysterious Source of the power and the intensity that makes the actor vibrate often seemingly far beyond any conceivable natural strength." ${ }^{30}$ Avatars are not mystics or saints in the usual sense: instead they form the connection between the human and the divine, representing utterances of destiny meant for wider masses.

\section{(2.2) Greater faith}

In this chapter Rudhyar proceeds to refine and specify his concept of transpersonality, focusing especially on a specific understanding of the term "law".

According to Rudhyar, law in the traditional sense is more or less a rule imposed from outside by an authority (in the most extreme case sanctioned by a god). He then interprets the idea of law, especially of the "divine plan of creation", from a metaphysical point of view: "The important point in any discussion of the concept of 'law' is whether or not the 'system of rules and regulations' is external to that which is being ruled, or inherent in whatever follows the rules. Unfortunately, in our misuse of words [...] we make no difference between a rule imposed from the outside and an inherent or instinctive compulsion to act according to a structural order." ${ }^{31}$ The true law is, according to Rudhyar, more of a "prinicple of organic order", ${ }^{32}$ an inherent order of reality - and losing the connection to this organic order creates a need for a law sanctioned by authority, whether human or divine. Nevertheless, when beings have a fully developed sense of basic character or nature of everything that exists, there is no need for an external authority that would establish and enforce laws. Rudhyar uses an example of a structure: "Let every worker be a true builder able to see or feel as an imminent compulsion the whole image of the building and particularly his place and his job in the building process - and there would be no need of rules and regulations by a managing boss." 33

For this kind of inherent principle of reality, Rudhyar employs a Sanskrit term, dharma - as he says, he uses it in a sense of the fundamental nature of anything that equals its function in a universal Whole or all-encompassing wholeness. A being, which follows its nature, does not have to obey an order - but if the being goes against its nature, it can betray it. Rudhyar adds that this inherent character of everything that exists is love or compassion. ${ }^{34}$

${ }^{30}$ Rudhyar, "Occult Preparations for a New Age", http://www.khaldea.com/rudhyar/op/op_c8 p4.php, part 3, chapter 8, p. 4.

${ }^{31}$ Rudhyar, "Occult Preparations for a New Age", http://www.khaldea.com/rudhyar/op/op_c9 p1.php, part 3, chapter 9, p. 1.

32 Rudhyar, "Occult Preparations for a New Age", http://www.khaldea.com/rudhyar/op/op_c9 p1.php, part 3, chapter 9, p. 1.

33 Rudhyar, "Occult Preparations for a New Age", http://www.khaldea.com/rudhyar/op/op_c9 p2.php, part 3, chapter 9, p. 2.

34 Rudhyar, "Occult Preparations for a New Age", http://www.khaldea.com/rudhyar/op/op_c9 _p2.php, part 3, chapter 9, p. 2. 
Nevertheless, the ability to follow one's true nature is not reached through libertinism and excess, but by means of hard work, transformation of egoistic matter of the emerging individual into a "translucent lens" that focuses a transpersonal shine of compassion: "One overcomes the need for obedience only through implicit readiness to obey. Then, when there is no longer any ego-block against utter obedience - and against humility or even humiliation - what was ego within the mind becomes a clear lens focusing the quality of the Soul into acts of destiny in which the dharma-individuality radiates as a transforming and illumining power." ${ }^{35}$ It means that true freedom is not an egoistic willfulness, but the adherence to the real truth of one's own being; while its certainty and unequivocal nature resembles instinct or an act determined by a tribal society, the transpersonal act is chosen consciously, since the person has already reached and transcended the state of developed ego or individuality. It is paradoxical that to reach this kind of spiritual transparency, a person needs to pass through a phase of spiritual blindness that is only characteristic of a seemingly free individual. Only a world where a transpersonal type of being has developed can exist without laws.

Rudhyar formulates one, and only one, Supreme Law as follows: "There is only one Supreme Law: Everything is as the need for harmony requires. Everything acts in order to satisfy what, at the time and to the best of its knowledge, it feels it needs. Everything seeks to act according to its fundamental nature. ${ }^{36}$ Rephrasing Rudhyar's meaning: the core of every time cycle or space unit is a need that arises from the solutions of the past as well as a potential and archetypal solution that arises and actualizes itself in every cycle. This solution is a manifestation of a virginal ocean of infinite potentiality that serves as a source for openness to new possibilities - in other words, a future. This tendency to satisfy one's need for harmony seems to be the same principle that Rudhyar calls One ${ }^{37}$ or Wholeness: ${ }^{38}$ "Man's nature, however, is to be conscious of the meaning of the infinite and cyclic interaction of need and solution; for only thus can he be what he essentially is: a Localizing agent for the power of the metacosmic Principle of Individual Existence which I have called simply (in capital letters) ONE. This Principle or Essence (the words are most inadequate, alas!) is what is at the root of eternal, cyclic MOTION." ${ }^{39}$

The trust in laws established by an external authority cannot be separated from an ego - but in this sense it is relative to a specific evolutionary stage of human development. It is to this development that Rudhyar's thinking was probably meant to

${ }^{35}$ Rudhyar, "Occult Preparations for a New Age", http://www.khaldea.com/rudhyar/op/op_c9 _p2.php, part 3, chapter 9, p. 2.

${ }^{36}$ Rudhyar, "Occult Preparations for a New Age", http://www.khaldea.com/rudhyar/op/op_c9 _p3.php, chapter 3, part 9, p. 3.

37 Rudhyar, "Occult Preparations for a New Age", http://www.khaldea.com/rudhyar/op/op_c9 _p3.php, chapter 3, part 9, p. 3.

38 Rudhyar, "Occult Preparations for a New Age", http://www.khaldea.com/rudhyar/op/op_c9 _p3.php, chapter 3, part 9, p. 3.

39 RudhyAR, "Occult Preparations for a New Age", http://www.khaldea.com/rudhyar/op/op_c9 _p3.php, chapter 3, part 9, p. 3. 
serve. This "greater faith" is the trust in "the inexhaustible potentiality of SPACE and in the omnipresence and all-harmonizing potency of spirit." ${ }^{40}$ This means an essential openness and a conscious acceptance of the role of focus of higher forces, where the subordination to external authority yields to an understanding of the inner sense of events - and to acceptance.

\section{(2.3) Love on the transpersonal way}

Another important aspect of Rudhyar's concept of transpersonal life is love between man and woman. The importance of this motif lies in the fact that the overall state of the society is, according to Rudhyar, anchored in the quality of interpersonal relationship, especially in the relationships between men and women. Rudhyar distinguishes two basic levels on which a love affair might take place: "It may operate as an unconscious biological, social, and psychological compulsion, or else as a consciously acknowledged, polarized, and transfigured power, used by mature personalities, in the service of a freely accepted superpersonal purpose." ${ }^{\text {11 }}$

The basic level of sexual relationships is the mostly instinctive biological type that is rooted in community life and is almost completely subordinated to the dictate of biological or social dimension of existence. Sex is viewed here as a mere tool for procreation.

As the individual consciousness slowly emerges from the collective substrate, love begins to appear: it is love of a sublime kind, or Bhakti - and, as Rudhyar says, from it raises the "theotropic" religiosity of mystics. In the situation of strengthening individualism and atomization, another kind of love appears, only this time its source is the inner emptiness of unfulfilled individuality. This is romantic or "erotropic love" and its goal is the ardent eroticism itself. Both these types of love share the same trait: "In both cases, the purpose of the love is lost in the thrill or rapture of the experience of love. The participants are inwardly forced into the tormenting fire or the blinding light of such a love." ${ }^{42}$ We might add that there is no freedom in the world of these passions, and sexuality becomes a mere tool of unconscious, self-forgetting unions, which is somehow similar to the states that Rudhyar attributes to the mystics.

The main function of this love lies in its ability to awaken consciousness - especially in contexts when it becomes a revolutionary force that transcends social barriers the aspect of fertility recedes to the background. Its power is more destructive than creative, a power that, by means of breaking and burning barriers, tends to adhere to one of the worlds.

Only a mature personality can stop trying to fill its own emptiness with a loved one and be able to strive for a deliberate and purposeful sharing of its own fullness.

${ }^{40}$ Rudhyar, “Occult Preparations for a New Age”, http://www.khaldea.com/rudhyar/op/op_c9_ p3.php, chapter 3, part 9, p. 3.

${ }_{41}$ RudhYAR, “Occult Preparations for a New Age”, http://www.khaldea.com/rudhyar/op/op_c10_ p1.php, chapter 3, part 10, p. 1 .

${ }^{42}$ Rudhyar, “Occult Preparations for a New Age”, http://www.khaldea.com/rudhyar/op/op_c10_ p1.php, chapter 3, part 10, p. 1 . 
In this moment the love of two beings, who have decided to join forces and head towards a shared transpersonal goal, gains its creative character back. Here, in contrast to earthly fruit of fertile biological love, something else is born: "The type of 'seed' which this co-productivity seeks to increase through an earth-transcending kind of cultivation is an ideospiritual or, symbolically speaking, 'celestial' type of seed - the seed of man's personal immortality, as well as the seed of a new culture established in the fullness of conscious human interchange. ${ }^{\$ 3}$ Nevertheless, individual human maturity is reached only at a point when the person is capable of letting go of his "cramps of the conscious" and start walking a transpersonal path: "As the man and woman unite their beings in the ritual of a consciously all-inclusive, transpersonal love, the bipolar emanation of the Divine becomes a concretely creative and transforming act of power. This is accomplished through the love of man and woman." ${ }^{44}$

In the union of man and a woman who have decided to devote themselves together to a higher whole and to the descent of spiritual energies through their persons, human love as well as transpersonal influence reaches a higher level. This type of spiritual influx is always a creative response to a concrete need that arises on higher levels of reality: "Creation is God's answer to a world in chaos, to the need of that which has come to experience total disintegration and the atomizing of matter utterly unillumined by spirit. Creation is a perpetual reestablishment of universal Harmony." ${ }^{5}$

Man is able to contribute to this kind of act - even more so when it comes to man and woman together. The definitive completion of this contribution is when they decide to enter into the pleromatic community of devoted beings that work together on the creation of a (probably somehow hermaphroditic) "Seed Man" that is the apex of the evolution of earthly humanity. "In that bipolar Man, the divine Word that was 'in the beginning' is made fully concrete, and the power of divine Nature is condensed; as in the seed, archetypal structure and potency of life are combined." ${ }^{46}$ This full actualization of the primordial potentiality of the archetype of man is meant to be a seed from which, so to say, a cosmic tree of the next cycle is supposed to grow: a new potentiality which, on its way to its new and full actualization, will be enriched by the things that happen on this way. In Teilhard's symbolism, which Rudhyar frequently used, the fulfilled and whole "hermaphroditic" Omega of one cycle becomes an Alpha of the next, although in each cycle the basic tuning of this principal tone or melody is different, as it is always specifically colored by the harvested experiences of the previous cycle. This kind of perpetual renewal is made possible by the infinite potentiality, or virgin ocean, of the primeval space, that enables a specific manifestation of each and every cycle.

${ }^{43}$ Rudhyar, "Occult Preparations for a New Age”, http://www.khaldea.com/rudhyar/op/op_c10 _p2.php, part 3, chapter 10, p. 2.

${ }^{44}$ Rudhyar, "Occult Preparations for a New Age”, http://www.khaldea.com/rudhyar/op/op_c10 _p2.php, part 3, chapter 10, p. 2.

${ }_{45}$ Rudhyar, "Occult Preparations for a New Age", http://www.khaldea.com/rudhyar/op/op_c10 _p2.php, part 3, chapter 10, p. 2.

${ }^{46}$ Rudhyar, "Occult Preparations for a New Age”, http://www.khaldea.com/rudhyar/op/op_c10 _p2.php, part 3, chapter 10, p. 2. 


\section{(2.4) The repotentialization and the virgin state}

In the next part, Rudhyar puts his thoughts in a metaphysical context. He speculates about the only possible inception of what we know as the universe as being about the road from potentiality to actuality, specifically about the emergence of "cosmic actuality" from the "metacosmic potentiality". ${ }^{47}$ As could be easily guessed, instead of the idea of god as a personal initiator of this mysterious act, Rudhyar suggests an alternative: "This metacosmic reservoir of potential energy may be significantly symbolized as an infinite Ocean of Potentiality." ${ }^{48}$ This ocean of potentiality is hard to fathom - while it cannot be described as "existing" in the usual sense, it can hardly be characterized as nonexistent. Rudhyar therefore speaks about "insistence" (as opposed to existence) in the sense of a latent or unamnifest state. ${ }^{49}$ This state, whose dominant traits are unity or subjectivity, is not absolute but temporary: the states of manifested and unmanifested being are always relative in some sense and the core of their being is their mutual cyclical interaction marked by a changing ratio of the opposing principles which never completely cease to operate. It is important not to mistake the One (in the sense of wholeness) with the principle of unity. Wholeness in this sense is non-dualistic and it encompasses and transcends the relativity of the opposing forces of unity and diversity.

That means that there are two different basic trends in existence: firstly, the trend towards actualization, realization of potentiality, and repotentialization, i.e. the second entry to the ocean of potentiality. The second trend can manifest itself existentially as deliberate refraining to identify oneself with anything from the revealed world, whereas the first may manifest as a compassionate acts.

The appearance of man, especially as a conscious individual, announces that in the cyclical movement of the reality we are again approaching the "equinox" or the point of balance between the principle of unity and the principle of diversity. Subsequently, a period of dominance of the principle of subjectivity is to come - just as, as Rudhyar says, a seed of the next existence is formed in the period between death and another incarnation. ${ }^{50}$

Part of human existence is thus formed by the ability of repotentialization, "a conscious and deliberate self-renewal." ${ }^{51}$ The first requirement to reach this ability is the belief that it can be reached: "The first condition is to believe in the possibility of it." 52

Depending on religious or metaphysical convictions consciousness "attunes" to what it perceives as a symbol of never-ending potentiality. In a mind that is able

${ }^{47}$ RudhyaR, “Occult Preparations for a New Age”, http://www.khaldea.com/rudhyar/op/op_c11 _p1.php, part 3, chapter 11, p. 1 .

${ }^{48}$ Rudhyar, "Occult Preparations for a New Age”, http://www.khaldea.com/rudhyar/op/op_c11 _p1.php, part 3, chapter 11, p. 1 .

${ }^{49}$ Rudhyar, Rhytm of Wholeness, http://www.khaldea.com/rudhyar/rw/, part 2, chapter 4, page 1.

${ }^{50}$ Rudhyar, The Planetarization of Coinsciousness, p. 175-188.

${ }^{51}$ Rudhyar, "Occult Preparations for a New Age”, http://www.khaldea.com/rudhyar/op/op_c11 p2.php, part 3, chapter 11, p. 2.

52 RudhyAR, "Occult Preparations for a New Age”, http://www.khaldea.com/rudhyar/op/op_c11 _p2.php, part 3, chapter 11, p. 2. 
to overcome the limitations of its past, "the divine grace" can cause a rebirth. By this means, the "sixth root race" of the Theosophist might arise - and Rudhyar connects this new step on the evolutionary path of mankind with the activation of the archetype of "Eternal Virgin": "To the Occultist, SPACE, abstractly considered as the infinite ocean of potentiality, takes the idealized and mythic character of the Eternal Virgin, for the virginal state symbolizes the possibility of any future manifestation." ${ }^{53}$ The "Eternal Virgin" represents a potentiality that is able to embrace and realize the divine "logos" - and, in the form of a Mother, it devours potentiality and enforces actuality. "The Virgin and the Mother represent therefore two fundamental images or archetypes of womanhood. They are two basic aspects of the Eternal Feminine symbols of potentiality and actuality." ${ }^{44}$

Whole societies can be characterized according to the principle they emphasize. After the reign of the mother that took place in the U.S. of the fifties, Rudhyar sees the revolt of the sixties as, among other things, a less successful attempt to "repotentialize", that nevertheless tended to potentiality, mostly in the sense of reverting to a chaotic state. Rudhyar suggests an integration of these symbols - on the one hand we have the virgin, which is fully concentrated on future things, on the other we have the mother, entirely consumed by actuality. The virginal state thus means "a state of being in which the natural condition of productivity for exclusivistic goals implying possessiveness is transcended." ${ }^{55}$ We can say that the symbol refers to creative potential free from attachment. This type of virginity is not limited to women, but acts as a symbol of creative transpersonal activity: "A creative process occurs through him, rather than from him. If he does not remain attached to it, and possessive of it, he remains virginal. ${ }^{56}$

A man that gravitates towards the past would tend to look for a motherly type of woman, a man of the future would prefer a virginal one. She can be an inspiring Muse and "a Holy Sister upon the mystical Path." ${ }^{7}$

In a relationship of this kind, sex should be free of biological compulsion and the flame of passion would be transmuted to a spiritual light. "Such an alchemical, deeply quiet and unemotional process is, however, most difficult to accept or even to understand for vitally exuberant persons avid for orgiastic release, or for individuals tense with frustrations, tragic hurts, and perhaps guilt complexes." ${ }^{\text {}}$ This process might even be dangerous for people like this - thence the understandable emphasis

${ }_{53}$ RuDhYAR, “Occult Preparations for a New Age”, http://www.khaldea.com/rudhyar/op/op_c11 _p3.php, part 3, chapter 11, p. 3.

54 Rudhyar, "Occult Preparations for a New Age", http://www.khaldea.com/rudhyar/op/op_c11 _p3.php, part 3, chapter 11, p. 3.

${ }_{55}$ Rudhyar, "Occult Preparations for a New Age”, http://www.khaldea.com/rudhyar/op/op_c11 _p3.php, part 3, chapter 11, p. 3.

${ }_{56}$ Rudhyar, "Occult Preparations for a New Age", http://www.khaldea.com/rudhyar/op/op_c11 _p4.php, part 3, chapter 11, p. 4.

57 Rudhyar, “Occult Preparations for a New Age”, http://www.khaldea.com/rudhyar/op/op_c11 _p4.php, part 3, chapter 11, p. 4.

${ }_{58}$ RudHYAR, "Occult Preparations for a New Age", http://www.khaldea.com/rudhyar/op/op_c11 _p4.php, part 3, chapter 11, p. 4. 
on a vote of chastity in those relationships, which can protect the couple against isolation that comes with the egoistic lingering on erotic happiness. ${ }^{59}$

If this kind of isolation is reached, sooner or later the cycle closes on the same level as it began - and the next one must also begin on the same level. "This is Samsara, the ever-resurgent urge to repeat the past, whether individually as a separate individual self, or collectively as a generation compelling the following generation by unconscious pressures and semi-hypnotic example to repeat its patterns or to rush rebelliously to the exact opposite, which is as compulsive and binding a procedure as unconscious imitation." ${ }^{60}$

The only possible alternative is a refusal to close the cycle in exhaustion combined with relentless and persistent repotentialization. It is "a breakthrough into the realm of those who, as brothers and sisters, exist in a state of ever-renewed potentiality and essential virginity which is indeed Nirvana, the condition of infinite latency from which all is possible and nothing is ever final or finished." ${ }^{61}$ Although this state does not equal timelessness, it still differs from time, or, better said, it penetrates its core and its source. "We are time. Consciousness is time, cyclic, rhythmic, harmonic, whole in its divine condition, as an Eon." ${ }^{62}$ Human confusion arises from the erroneous identification of a human with only one of the phases and not with the entirety of time: "We potentially are the whole cycle; more still we have in us the potentiality of always breaking through the fulfillment of any cycle into the vast measureless Movement which unceasingly calls forth new potential out of the infinite expanse of Virgin SPACE, within and from which all is possible." ${ }^{63}$ According to Rudhyar, the intent to escape from this movement and reach some kind of timelessness is illusory. "The now, lived in full concentration on the potentiality it is called upon to release as one phase of a vast cycle, is one with the cycle - IF the wholeness of the cycle is evoked and focused in the act here and now. This is avatarhood, divine manifestation. This is the transpersonal way." ${ }^{64}$

\section{(2.5) Through crises - new beginnings}

Finally, the author contemplates the problem that getting on the transpersonal path means a deep crisis of the individuality that heads towards transformation. A relationship with a real guru, which is associated with this kind of path, leads the pupil into a crisis, in which he is confronted with the karmic remains of the past. The har-

${ }^{59}$ Rudhyar, “Occult Preparations for a New Age”, http://www.khaldea.com/rudhyar/op/op_c11 _p5.php, part 3, chapter 11, p. 5.

${ }^{60}$ Rudhyar, “Occult Preparations for a New Age”, http://www.khaldea.com/rudhyar/op/op_c11 _p5.php, part 3, chapter 11, p. 5.

${ }_{61}$ Rudhyar, "Occult Preparations for a New Age", http://www.khaldea.com/rudhyar/op/op_c11 _p5.php, part 3, chapter 11, p. 5.

${ }^{62}$ Rudhyar, "Occult Preparations for a New Age”, http://www.khaldea.com/rudhyar/op/op_c11 _p5.php, part 3, chapter 11, p. 5.

${ }_{63}$ Rudhyar, "Occult Preparations for a New Age”, http://www.khaldea.com/rudhyar/op/op_c11 p5.php, part 3, chapter 11, p. 5.

${ }^{64}$ Rudhyar, "Occult Preparations for a New Age”, http://www.khaldea.com/rudhyar/op/op_c11 _p5.php, part 3, chapter 11, p. 5. 
vest of the karmic past is directed to the pupil through the guru: in a similar way, the presence of an avatar among the people brings about a crisis. In the case of a strong individual a guru is not needed, since the crisis is triggered by life itself - although the Master is always present behind the scenes. "As the ship is left loose to brace the currents and storms of the immense sea of an astral realm that one can only reach through as well as beyond the solid physicality of our everyday world, the life of the self-consecrated individual produces radical crises. Crises are thresholds which one must pass through; what counts is the essential quality of the movement through." ${ }^{\prime 6}$ The success or failure is measured by the quality of being: the final decision consists in the moment, in which all the energies of the personality concentrate in one basic act of affirmation or refusal. This process always contains suffering - either the negative type, in which the ego struggles to hold things together by force, or a suffering that arises from the struggle against supremacy of the ego. This suffering is not a typical kind of pain - it is pain that the person lives through consciously. "He who is following the transpersonal Way and is definitely ready and intent upon entering the Path - the path of total transformation - can expect to travel with suffering as his companion. He has deliberately entered a process of transition."66

Thus the transition between two levels invariably contains suffering. According to Rudhyar, in the current era we are experiencing a transition of culture - first from the tribal state to the individual, since, as we already know, Rudhyar insists that in the case of most of people, the individual functions are developed only partially and imperfectly. Even this transition is marked by considerable tension. At the same time we are going through another complicated process, which is the development of transpersonal functions in those people that were able to finish their individualization and managed to surface from the collective substrate of their own ethnicity and culture. A person that sets out on the transpersonal path is exposed to one more type of suffering - he or she has affiliated his or her existence to a different level of consciousness and being, nevertheless the person still lives on the biological, social and individual level. Until he or she fully reaches the other side, the transpersonal life, he or she will still be a carrier of the previous levels of functions and thus will suffer from inner conflicts. Even though the process would probably never be possible to finish without the help of those who have already gone through it, the main share of work is reserved for the aspirant. "Yet, helped as he undoubtedly is, he alone must do the crossing; he alone must fight against the powerful current of material entropy, against overwhelming weariness, loneliness, and an insidious sense of futility." ${ }^{67}$ These efforts to transform are necessarily repetitive - it is necessary to keep beginning from scratch and, while in contact with the infinite potentiality, struggle to

\footnotetext{
${ }^{65}$ Rudhyar, “Occult Preparations for a New Age”, http://www.khaldea.com/rudhyar/op/op_c12 _p1.php, part 3, chapter 12, p. 1.

${ }^{66}$ Rudhyar, "Occult Preparations for a New Age", http://www.khaldea.com/rudhyar/op/op_c12 _p1.php, part 3, chapter 12, p. 1.

${ }^{67}$ Rudhyar, "Occult Preparations for a New Age", http://www.khaldea.com/rudhyar/op/op_c12 _p2.php, part 3, chapter 12, p. 2.
} 
transform the wheel of infinite repetition of previous mistakes into a spiral, a symbol of openness to transformation. "The new possibility is always present; but the individual has to be ready with his unsheathed will. His hand does hold the sword, but the spirit, God, will move the hand if the man's consciousness is ready and willing to let go. Then the goal will be struck." ${ }^{\prime 8}$ It is necessary to stay open to the unexpected and miraculous: "We must dare to summon the potentiality of an essentially new and, for us, unprecedented beginning." ${ }^{69}$ Those crises thus stimulate our openness to a new beginning - and the real risk is not in experiencing them, but in resignation, refusing the offer of transformation and settling down in the comfort of the familiarity and numbness of a dead past. "Courage, faith, and throughout the whole way, love, and clarity of mind: these are the essential requirements for whoever dares to enter the Path, the path of ever-renewed transformation." ${ }^{\prime 70}$

\section{(3) Transpersonality and mediumity}

Our goal to present Rudhyar's concept of transpersonal life would remain incomplete if we fail to point out one more important aspect of this understanding of existence that is its difference from a seemingly akin concept of mediumity. The difference between transpersonality and mediumity ${ }^{71}$ might be residual remains of past quarrels between Theosophy and Spiritualism; nevertheless, Rudhyar attributes a wider and more general meaning to it.

A transpersonal being, through which flows an influence of higher or fuller wholes, energies, or consciousness fields, must have some dispositions and capacities to make this influences possible. As Rudhyar comments: "A 'transpersonal action' can refer to the release through a person of either a stream of transformative energy, perhaps able to produce seemingly miraculous results, or of information not normally available to the present-day mind. Nevertheless, the person through whom the power or the information is released cannot be merely anyone, any more than a lens can be any piece of glass." ${ }^{2}$

Conversely, a medium lacks these dispositions, since unlike a really transpersonal individual, the medium is not an accomplished individuality, resembling more its shadow - it is a mere "shard" of the transpersonal individual's crystal-clear lens. Rudhyar warns against the influence of this kind of seemingly transpersonal individual:

${ }^{68}$ Rudhyar, "Occult Preparations for a New Age”, http://www.khaldea.com/rudhyar/op/op_c12 _p2.php, part 3, chapter 12, p. 2.

${ }_{69}$ Rudhyar, "Occult Preparations for a New Age”, http://www.khaldea.com/rudhyar/op/op_c12 _p2.php, part 3, chapter 12, p. 2.

${ }^{70}$ Rudhyar, "Occult Preparations for a New Age”, http://www.khaldea.com/rudhyar/op/op_c12 _p2.php, part 3, chapter 12, p. 2.

${ }_{71}$ RudhYAR, Rhytm of Wholeness, http://www.khaldea.com/rudhyar/rw/, part 4, chapter 13, page $1-4$.

${ }^{72}$ RudhYAR, Rhytm of Wholeness, http://www.khaldea.com/rudhyar/rw/, part 4, chapter 13, page $1-4$. 
"Above all the distinction between mediumistic 'communications' and transpersonal transmission [...] must be made clear. If this distinction is not made, the ideal of transpersonal living may become negative and potentially dangerous." ${ }^{\text {"33 }}$

Transpersonality, as opposed to mediumity, is not only characterized by activity, but also by a specific, altruistic motivation: "Relatively exact transpersonal communications from a Pleroma being to a 'disciple' occur only to the extent the receiving human personality has made himself or herself steadily attuned to the vibration and power of the spiritual Source, and also to the extent the motive for accepting the role as intermediary has been entirely free from ego, pride, and subtle self-glorification." ${ }^{74}$

We can summarize that Rudhyar's transpersonality represents a complex outline of a spiritual life formed by ethical, cosmic and existential aspects. Transpersonal influence is, or should be, characterized by an active participation in the world's affairs, since its motive is always the fulfillment of an actual need of a greater whole, but also by a kind of resignation - it is less of a voluntarist shaping of the surrounding actions and more listening to the nature, "dharma", and uninterested acting in harmony with it. It seems that this type of concept is a kind of synthesis of the eastern "passivity" and contemplative immersion with the western "activity" and interest in the outward reality; a synthesis that Rudhyar, who was then 35 years old, already outlined in his first bigger treatise on his "philosophy of operative Wholeness." his concept of transpersonal life had the ambition to become the ethos and spirituality of the future mankind - and that it possibly aimed even higher. We shouldn't be surprised that both in his early and late texts Rudhyar speaks of his philosophy, cautiously but undeniably, as being about a revelation of a new referential framework of reality, which is created through his work - and, consequently, through the personality of its creator. ${ }^{76}$ We may add that Rudhyar was probably not the only one who attributed these transpersonal qualities to his influence. Rudhyar's old friend, and one of the few direct followers, Michael M. Meyer writes about his first meeting with him: "As he spoke his voice rolled like thunder through the hall. The Tone of a mighty gong seemed to sound through Rudhyar; and my mind, being and consciousness resonated to it. The air, and our minds, vibrated with the spiritual power that seemed to flow through Rudhyar like light through a window. Everyone in the hall seemed utterly fascinated with Rudhyar. I realized I was encountering a living representative of the Community of Seers and Sages."ㄱ

\footnotetext{
${ }^{73}$ Rudhyar, Rhytm of Wholeness, http://www.khaldea.com/rudhyar/rw/, part 4, chapter 13, page 1.

${ }^{74}$ RUDHYAR, Rhytm of Wholeness, http://www.khaldea.com/rudhyar/rw/, part 4, chapter 13, p. 2.

75 DANe Rudhyar, “A Philosophy of operative Wholeness" (online), Khaldea.com, 1995, accessed March 2016, available online at http://www.khaldea.com/rudhyar/pow_1.shtml.

${ }^{76}$ RUDHYAR, Rhytm of Wholeness, http://www.khaldea.com/rudhyar/rw/, part 1, chapter 1, page 6.

77 Michael Meyer, "Rudhyar - Friend, Exemplar and Sage" (online), Khaldea.com, 1995, accessed March 2016, available online at http://www.khaldea.com/articles/dr_fes.shtml.
} 


\section{(4) Rudhyar in context: predecessors, associates and heirs}

Rudhyar lived a seemingly rich social life and maintained contact with a great many important artistic and spiritual movements of his time; nevertheless, when reading his many works and studying his life one can hardly avoid the impression that regardless of it all he was a very lonely type of thinker. Even though, in many ways, he was certainly a pioneer, he would never have been credited, however cautiously, in his life had he not live to an advanced age. ${ }^{78}$ If we take into consideration his philosophical or spiritual heritage, he was probably closest to Theosophy; however, he never became a member of the Theosophical society and his respectful but nevertheless critical interpretation of Theosophy is hardly possible to be deemed orthodox. He influenced directly or indirectly and, we might add, admittedly or unadmittedly - many authors, but he never founded his own school and there are only a few direct followers.

In this context, at least an intention to place Rudhyar in the wider context of the spiritual currents of the era may throw some light on the heritage of this curious lone wolf and autodidact. We must examine only those connections that closely relate to his concept of transpersonality; in another context we would certainly have to mention Western Philosophy and Psychology of the 19th and 20th centuries, Eastern thought, and a few artistic currents that either influenced Rudhyar or were influenced by him.

The single most obvious connection is the link between Rudhyar's legacy and Theosophy. In his youth, the author used to spend hours every day studying theosophical literature and we must admit that its influence in his works is undeniable. Reading Rudhyar's works parallel to the books of H. P. Blavatsky, we soon realize that instead of searching for more and more infinite parallels we might ask in which points Rudhyar actually differs from the founding figure of the Theosophical movement. He answers this himself in the mentioned book he dedicated to Theosophy. He understands the movement as a historically limited tradition and merely one of many spiritual traditions (in other words, he does not see it as a full articulation of a universal, perennial tradition). He does not see Blavatsky's detailed descriptions of cosmic and historic events as a literal account of what really happened, but more as a symbolic articulations that serve to develop the reader's sense for a universal cyclical process of cosmic adventure. In our context it is important that the model examples of "pleromatic" beings that, according to Rudhyar, act through transpersonal individuals may have been Blavatsky's "Masters". However, even in this case Rudhyar tends to understand these figures not as personifications or limited persons, but more like fields of consciousness. Therefore Rudhyar, in his concept of transpersonality, can also be understood as an unorthodox Theosophist, who tends to interpret the basic texts in a processual, symbolic, and metaphoric way. Michael Meyer also suggests that we could understand Rudhyar's interpretation of Theosophy as the "new, more inclusive message and world-

${ }^{78}$ Rudhyar lived to 90 years old and created his most famous works in his last years - his philosophical summa Rhytm of Wholeness was written in 1983, while the author died in 1985. 
view would be needed, released and formulated during the last quarter of the 20th century," that Blavatsky spoke about in the late years of her career. ${ }^{79}$

In our context we can hardly avoid Rudhyar's relationship to the later transpersonal movement. Rudhyar himself leaves little room to doubt that he somehow distanced himself from this movement and that his concept of the "transpersonal" (which is a neologism of his own, as he, perhaps without bitterness, but nevertheless emphatically and frequently reminds his readers $)^{80}$ is virtually the opposite of its later version. In seems that "transpersonality" in the sense of altered states of consciousness or a widening of the mind was for Rudhyar merely a part of "Mysticism", which he sees as appropriate for some historical eras but in present times he finds it more or less obsolete, if not contrary to the current trend of evolution..$^{81}$ This kind of disparity seems to be a common denominator that rules the relationship of Rudhyar and the authors of the transpersonal movement: if we consider the "Paths Beyond Ego: The Transpersonal Vision" 82 as a typical representative of the movement, the reading confirms Rudhyar's conviction that except for the term itself that the authors used, perhaps unknowingly, but in most cases certainly without quoting the source, his concept of transpersonality is entirely different from theirs. It is symptomatic that the mentioned book not only does not contain any of Rudhyar's text or a mention of it, but that it fails to mention any of it in the extensive bibliography. As far as we know, this situation often repeats itself in the works of later transpersonalists. ${ }^{83}$

On the contrary, there is a considerable and surprising likeness between Rudhyar's concept of transpersonality and the idea of sacred tradition among his contemporaries - sometimes also his compatriots - from the Perennialism movement. The single most typical trait of this group of thinkers, which Rudhyar shares with them, is probably their belief that there is a universal sacred tradition. ${ }^{84}$ This analogy is even more remarkable, since neither the traditionalists' nor Rudhyar's works show evidence they knew about each other. However, this interesting parallel in the key motif of sacred tradition is not to be overestimated: radical cultural pessimism and shared

${ }^{79}$ Meyer, "Rudhyar - Friend, Exemplar and Sage", http://www.khaldea.com/articles/dr_fes.shtml.

${ }^{80}$ Rudhyar comments on this in his main work: "To my knowledge I was the first to use the term though C. G. Jung may already have used it in German without my being aware of it - in an article in the magazine The Glass Hive (1930) edited by Will Levington Comfort. The word came into wider use in 1968 when Abraham Maslow, Anthony Sutich, and other psychologists started the Association for Transpersonal Psychology in Palo Alto, California." RUdHYAR, Rhytm of Wholeness, http://www.khaldea.com/rudhyar/rw/, part 1, chapter 2, page 2.

${ }^{81}$ RudHYAR, “Human.All TooHuman -AndBeyond”, http://www.khaldea.com/rudhyar/toohuman shtml.

82 Roger Walsch and Frances Vaughan (eds.), Paths Beyond Ego: The Transpersonal Vision, Los Angeles: J. P. Tarcher/Perigee, 1993, 293 p.

${ }^{83}$ This is seemingly confirmed by the program of the last Czech transpersonal conference (23th-24th April 2016 in Prague), which can still be accessed on the webpage http://www.ctk2016.cz/ [29. 4. 2016]. The question of the relation between Rudhyar and those authors that use astrology and at the same self-identify as a part of the complex transpersonal movement of today (such as Richard Tarnas) is very complex and cannot be addressed in this article.

${ }^{84}$ Wouter J. HanegraAfF (ed.), Dictionary of Gnosis \& Western Esotericism, Leiden, Boston: Brill 2006, p. 1132. 
conviction, according to which the modern world is not a manifestation of evolutionary progress of humankind, but instead an abomination and a monstrous falling off the traditional character of human society, another core trait of the traditionalists, was shared by Rudhyar only in a limited manner. ${ }^{85}$ Unlike the main representatives of traditionalism, he remained a historical optimist all his life, evolutionist - and, last but not least, also an essential democrat.

It seems Rudhyar could be also listed among the predecessors (and to some extent also associates) of the New Age movement. Although Rudhyar himself uttered some skeptical remarks towards the milieu and he is rarely counted among its representatives, ${ }^{86}$ he could be linked to the movement as a successor of Theosophy, which is undoubtedly one of the main sources of the New Age movement, as an important co-creator of contemporary Astrology and a devotee of the holistic approach to reality and a herald of an upcoming "new age". Even though we do find some important New Age motifs in Rudhyar's works, it is notable that, for example, his concept of transpersonality as opposed to mediumity is possibly more directed against channeling, which is one of the core characteristics of the New Age, ${ }^{87}$ than to the older Spiritualism. Rudhyar's late works, in particular, might be interpreted in New Age terms - not as favorable towards the movement, but contrasting with it. Rudhyar's relationship to the milieu is a paradox, since as a Theosophy-inspired author and an important Astrologer he somehow contributed to the origins and development of the movement. On the other hand, he might have tried to influence and cultivate it with his works.

This short and hardly comprehensive intent to put Rudhyar's work and his concept of transpersonality at least in a basic context seems nevertheless to underscore the originality of our thinker and emphasize the impossibility to attribute him to some movement or other. Nevertheless, it may serve to indicate Rudhyar's place on the spiritual map of the 20th century, which is, to a great extent, marked by his closer or more remote connections. If we stick to the metaphor, Rudhyar's work more resembles an independent island that actively pursues contacts with its many neighbors than a single state in a large federative whole.

\section{(5) Conclusion}

As we have seen, Rudhyar's concept of transpersonality represents a specific project of spiritual life, which is unrelated to later transpersonalism and which represents a core motif of his understanding of the existence of individuals, society, and hu-

${ }^{85}$ Nevertheless, Rudhyar sees this society as a failure too; see RUDHYAR, Beyond Individualism.

${ }^{86}$ In Wouter J. Hanegraaff's vast monograph dedicated to the New Age movement there is, as far as I know, no mention of Rudhyar whatsoever. Wouter J. HanegraAfF, New Age religion and western culture in the mirror of secular thought, New York: Brill 1996, 580 p.

${ }^{87}$ Hanegraaff, Dictionary of Gnosis \& Western Esotericism, p. 857; see also Rudhyar, Rhytm of Wholeness, http://www.khaldea.com/rudhyar/rw/, part 4, chapter 13, page 1-4. 
mankind as a biological species, but also of the cosmos as a conscious, alive, and organically interconnected whole, in which the evolution of both the individual and humanity as a whole has its irreplaceable function. If we see the history of thought and religious creativity of the past century as a quest for a new meaning of life and ontological security in a context of the disintegration of traditional religious worldviews and the "disenchantment" of the world, we could understand Rudhyar's concept of transpersonality precisely as the author's intent to overcome the existential frustration of the late Modern society. This intent is essentially a very traditional or even somehow conservative concept of cosmically situated and ethically binding spirituality. The single most specific trait of this spirituality is the fact that, since he is largely (albeit critically) inspired by Theosophy, Rudhyar also includes in his thoughts ideas about the evolution of both humanity and the cosmos, while in his case an important role is played here by modern art. ${ }^{88}$ This point shows probably the biggest tension in his thought: he sees transpersonality, which he describes with language pertaining to a supreme esoteric initiation, as the future of humanity itself. Esoteric initiation, which is traditionally reserved only for a few ${ }^{89}$ becomes a rite of passage, by means of which the future humanity - and contemporary vanguard shall enter a new age. This represents a radical transformation, hard to imagine for a common mind, during which the earthly matter changes to light and the objective outside world disappears; this gives Rudhyar's legacy a distinctly utopian or even apocalyptic feel. Transhistorical spiritual hierarchy of beings becomes in his works, such as in the writings of Blavatsky, an avant-garde of the forthcoming historical transformation..$^{90}$

However, Rudhyar's concept of transpersonality also has its complications. The first question is how we are supposed to reach the goal Rudhyar speaks about; what are the means by which the man is transformed into a light and how the pleromatic communities are established. It is not clear how the step from the complicated and noble ethos of a "devoted service" to a completion of alchemical work or reaching Vajrayana's diamond body should look like. We can learn from Rudhyar's works that this is what is supposed to happen, nevertheless if we are to take Rudhyar's program as seriously as he apparently did himself and if we are to try to reach somehow transpersonality itself, we find only a little inspiration in Rudhyar's books for a project like this. It seems that the author supposed some kind of a spontaneous planetary mutation, which would happen who knows when - Rudhyar's prognoses for the im-

${ }^{88}$ RUDHYAR, The Planetarization of Consciousness, p. 250.

${ }^{89}$ The meaning of "initiation" here equals René Guénon's concept as presented, for example, in his work dedicated to this topic: René GuÉNon, Aperçus sur l'Initiation, Paris: Éditions Traditionnelles 1946, $303 \mathrm{p}$.

${ }^{90}$ Nicholas Goodrick-Clarke mentions analogical tension in H. P. Blavatsky's work in his study of the concept of sacred tradition in Theosophical movement. See Nicholas Goodrick-Clarke, "The Coming of the Masters: The Evolutionary Reformulation of Spiritual Intermediaries in Modern Theosophy", in ANDreas B. Kilcher (ed.), Constructing Tradition, New York: Brill 2010, p. $113-160$. 
mediate future were mostly pessimistic. ${ }^{91}$ Rudhyar does not point the way towards how we are supposed to reach this both collective and individual necessary transformation - unless we count Astrology as a tool for transformation or transmutation. However, considering Astrology a sufficient tool to create results such as finishing the alchemical opus magnum or obtaining an indestructible body is very far-fetched even if we deem such radical transcendence of a profane human existence possible; in any case, no relevant tradition supports this claim.

Similarly problematic is Rudhyar's radical distinction between transpersonality and mediumity, which plays prominent role especially in his late works. The difficulty of distinguishing between the "crystal-clear ens" of a fully developed personality and a mere "shard" of the medium is well illustrated in H. P. Blavatsky's case. As it seems, Rudhyar took her unquestionably as an emissary of a "transhimalayan" occult brotherhood $^{92}$ and a transpersonal being, and this distinction was probably inspired by the quarrels between Theosophy and Spiritualism anyway. On the other hand, even though H. P. Blavatsky was undoubtedly an inspiring personality, her teachings and inspirational sources may provoke some doubts and unease. In her case, to separate transpersonal influences from mediumity, or even fraud, if even possible, is hardly an easy task. A question arises as to whether it is even possible to recognize authenticity that stems from higher levels of existence (if, of course, we agree that it exists) without a connection to a specific spiritual tradition; similarly, it seems to be difficult to recognize the authenticity of an esoteric initiation without a proper and reliable succession of initiates. The history of the Theosophical movement and, on a larger scale, of Western Occultism as such, offers a great number of examples of how difficult this question may be.

The most problematic point of Rudhyar's thought is the meeting, or closest approach, point of the transhistorical verticality of esoteric tradition and the horizontality of history and evolution. In the case of Rudhyar's legacy, we not only face the question of to what extent his utopian, and at the same time eschatological, visions are even believable and how probable or even possible is their accomplishment, which, from the perspective of humanity of the third millennium BC, is just as hard to prove as to disprove. It seems that more important question relates to the coherence of Rudhyar's worldview as such. He spent most of his life trying to reestablish a sense for a cyclical nature of time and to replace the religiousness related to a transcendent personal god with different, cosmic, impersonal or transpersonal spirituality. The question is whether his intent to integrate evolution theory and the idea of some kind of progress apparent in the history of mankind did not allow his biggest enemy - linear time, finite or at least directed towards some kind of end - to creep up stealthily into his concept of cyclical time. It is possible that the idea of transpersonality as a future of mankind (and not as an initiatory transcendence of historical spatiotemporality

91 Dane Rudhyar, “A Seed” (online), Khaldea.com, 1995, accessed March 2016, available online at http://www.khaldea.com/rudhyar/seed.shtml/.

${ }^{92}$ Rudhyar, "Occult Preparations for a New Age", http://www.khaldea.com/rudhyar/op/op_c6 _p1.php, part 1, chapter 3, p. 1. 
and transition to a radically different level of existence) is both the key to Rudhyar's system and its biggest weakness.

On the other hand, it is possible to approach not only these aspects of Rudhyar's legacy, but also the legacy itself, in the same manner as he himself approached the works of H. P. Blavatsky. It is possible that, just like her (at least in Rudhyar's interpretation), he also spoke particularly and deliberately to people with a specific mindset and worldview in order to change it - and after the transformation, the literal sense of his teachings would cease to be relevant. Rudhyar's philosophy of operative wholeness might have been conceived by its author as a phase which is necessary to pass through - and not as a rigid unchangeable system, but as one which would retain its validity even after it has been existentially adopted. The possibility of this interpretation seems to be suggested by Rudhyar himself at the very end of his opus magnum. He speaks about a long and difficult path of transformation, which questions the absolute truth of all the certainties and worldviews and on the top of which even the all-encompassing and universal infinite flow of transformations becomes relative. ${ }^{93}$ If, despite the fact that his experience of incessant transformation was frequently the foundation of his thought, Rudhyar relativizes in his greatest work the transformation itself, it seems to point out that we should take seriously his statements that his writings should not serve as a source of information about the cosmos and mankind, but primarily as a matrix for an emergence of a new type of mind. ${ }^{94}$ In other words: although it is certainly possible to analyze and interpret Rudhyar's concept of transpersonality, due to its nature any strictly theoretical approach necessarily fails to grasp it in its entirety.

\section{REFERENCES}

Goodrick-Clarke, Nicholas, “The Coming of the Masters: The Evolutionary Reformulation of Spiritual Intermediaries in Modern Theosophy”, in Andreas B. Kilcher (ed.), Constructing Tradition, New York: Brill 2010, p. 113-160.

GuÉnon, René, Aperçus sur l'Initiation, Paris: Éditions Traditionnelles 1946, 303 p.

Hanegraaff, Wouter J. (ed.), Dictionary of Gnosis \& Western Esotericism, Leiden, Boston: Brill 2006, 1230 p.

HANEgraAfF, Wouter J., New Age religion and western culture in the mirror of secular thought, New York: Brill 1996, 580 p.

Meyer, Michael, "Rudhyar - Friend, Exemplar and Sage" (online), Khaldea.com, 1995, accessed March 2016, available online at http://www.khaldea.com/articles/dr_fes .shtml.

RudhyAR, DANE, The Astrology of Transformation, A Multilevel Approach (online), Khaldea.com, 1995, accessed March 2016, available online at http://www.khaldea.com /rudhyar/aoft/.

Rudhyar, Dane, Beyond Individualism: The Psychology of Transformation, Wheaton: Quest Book, 1979, 153 p.

\footnotetext{
${ }_{93}$ RudhYAR, Rhytm of Wholeness, http://www.khaldea.com/rudhyar/rw/, epilogue, page 1-2.

${ }^{94}$ RUDHYAR, Rhytm of Wholeness, http://www.khaldea.com/rudhyar/rw/, prologue, page 1.
} 
Rudhyar, DANe, "From humanistic to transpersonal astrology" (online), Khaldea.com, 1995, accessed March 2016, available online at http://www.khaldea.com/rudhyar /fromhtot_1.shtml.

Rudhyar, DANe, "Human, all too human and beyond" (online), Khaldea.com, 1995, accessed March 2016, available online at http://www.khaldea.com/rudhyar/toohuman .shtml.

Rudhyar, Dane, “Occult preparations for a New Age” (online), Khaldea.com, 1995, accessed March 2016, available online at http://www.khaldea.com/rudhyar/op/op_c6 _pl.php.

Rudhyar, DANe, “On personal and impersonal” (online), The Glass Hive (November 1929), accessed March 2016, available online at http://www.khaldea.com/rudhyar /per_imper.shtml.

RUdhyar, Dane, “A Philosophy of operative Wholeness" (online), Khaldea.com, 1995, accessed March 2016, available online at http://www.khaldea.com/rudhyar/pow _. 1.shtml.

Rudhyar, Dane, The Planetarization of Consciousness, New York: Harper 1972, 343 p.

RudhyAR, DANE, Rhythm of Wholeness: A Total Affirmation of Being (online), Khaldea. com, 1995, accessed March 2016, available online at http://www.khaldea.com/rudhyar $/ \mathrm{rw} /$.

Rudhyar, Dane, “A Seed” (online), Khaldea.com, 1995, accessed March 2016, available online at http://www.khaldea.com/rudhyar/seed.shtml/.

Walsch, Roger, and Frances Vaughan (eds.), Paths Beyond Ego: The Transpersonal Vision, Los Angeles: J. P. Tarcher/Perigee, 1993, 293 p. 